\title{
ジャーナル軸受におけるキャビテーションの成長に関する研究
}

\section{Study on growth of cavitation in journal bearing}

\author{
○学 西田 一樹（久留米高専 専攻科） 正 大津 健史（久留米高専） \\ 正 石丸 良平 (久留米高専) 正 和泉 直志 (久留米高専)
}

Kazuki NISHIDA, Takefumi OTSU, Ryohei ISHIMARU, Naoshi IZUMI, Kurume National College of Technology, 1-1-1 Komorino, Kurume, Fukuoka

Key Words: cavitation, hydrodynamic lubrication, journal bearing, lubricant, gas

\section{1. 諸言}

潤滑部におけるキャビテーションの発生は，エロージョ ン, 潤滑膜の破断, 摩擦力の低下, 振動の抑制, 発泡など と関係し，潤滑性能に大きな影響を与える。キャビテーシ ヨンの発生を効果的に制御することが可能となれば，それ に関係した問題を防止することができ，また効率的な潤滑 面設計を行えるようにもなる，そのためには，各潤滑部に おけるキャビテーション現象を詳細に理解することが重要 となる。現象の一つに，キャビティー領域が時間とともに 拡大寸る成長現象が挙げられる。これまでに, その成長は 油中の溶解気体が時間とともにキャビティー内に析出する ことによって起こること, 溶解気体量が多くなる条件で成 長が大きくなることなどの特性が明らかとなっている ${ }^{1)}$.

本研究では，透明アクリル樹脂製軸受を用いたジャーナ ル軸受試験機を用い, キャビテーションの発生および成長 の直接観察を行った。また，軸受の偏心角，偏心量も測定 し, 軸受の偏心状態と成長現象の関係について検討した.

\section{2. 実験方法}

\section{1 実験装置}

Fig. 1 は実験装置の概略図を示す. 透明なアクリル樹脂製 の軸受と鋼製の回転軸を使用し, 油膜, およびキャビティ 一を直接観察できる構成となっている.

軸受は上方より支持し，コイルばねを介して軸受の自重 と同等の力で引き上げた. 回転軸(炭素鋼 S45C 製)はモータ 一と接続されており，その両端を玉軸受で支持した。荷重 は，軸受に設けた支持部より，ワイヤーを介して接続され た負荷部に錘を乗せることによって加えた，なお，荷重は 錘の数を変化させ，調整した。油槽は軸受下方に設け，軸 受と軸の一部(軸受の最下部から約 $35 \mathrm{~mm}$ )が入るようにし た。なお，油槽は透明なアクリル樹脂製である。

軸受は外径 $150 \mathrm{~mm}$, 内径 $100.14 \mathrm{~mm}$, 幅 $100 \mathrm{~mm}$ であり, 回転軸は直径 $99.5 \mathrm{~mm}$, 軸受部長さ $110 \mathrm{~mm}$ である. 半径

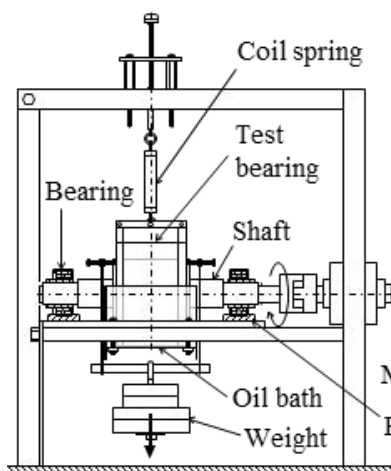

(a) Front view

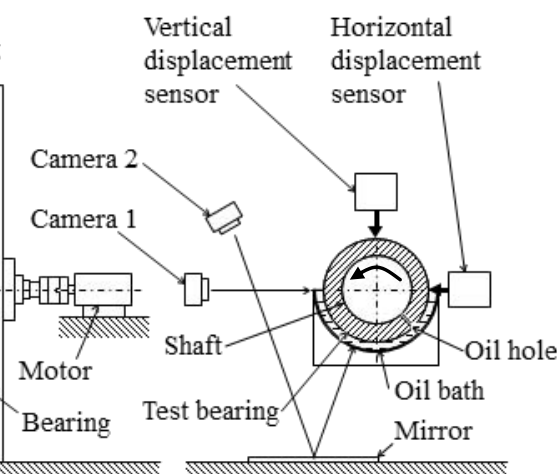

(b) Side view
Fig.1 Test apparatus
すきまは $320 \mu \mathrm{m}$ ，幅径比は約 1.0 である。なお，軸受には Fig. 1 に示すように直径 $6 \mathrm{~mm}$ の給油穴を 4 つ設けている. キャビティーの観察は，軸受正面，および軸受下方の 2 ケ所から行った。ただし, 下方からの像は, 鏡に映る像を 垂直位置から $30^{\circ}$ の角度で観察することによって行った. また，軸受の偏心位置を測定するために，軸受の垂直方向 と水平方向の位置を変位センサによって測定した。測定結 果を基に偏心量，および偏心角を求めた。

\section{2 実験条件}

実験条件は, 回転数 $22 \mathrm{rpm}$ 一定, 荷重 $20-45 \mathrm{~N}$, 潤滑 油温度 $300 \mathrm{~K}$ で行った。荷重は, $2 \mathrm{~min}$ 毎に $20 \mathrm{~N}, 30 \mathrm{~N}$, $40 \mathrm{~N}, 45 \mathrm{~N}$ と増加させた. なお, $45 \mathrm{~N}$ 時の平均面圧は 4500 $\mathrm{Pa}$ ，ゾンマーフェルト数は 0.034 である。潤滑油には，市 販品の軸受油を使用した。動粘度は, $11.3 \mathrm{~mm}^{2} / \mathrm{s} @ 313 \mathrm{~K}$ で あった。また，キャビティー領域を明確にするために，潤 滑油には蛍光物質を添加し，紫外光を照射した時に油膜が 蛍光を発し，キャビティー領域が暗くなるようにした。蛍 光物質にはピレンを用い，油に $0.3 \mathrm{wt} \%$ 添加した。

\section{3 キャビティ一領域の定義}

Fig.2 に，実験時の軸と軸受の位置関係を示す．図中で $\phi$ は偏心角, $e$ は偏心量, $h$ はすきま厚さ, $\theta$ は最大寸きまの 位置から回転方向に進む角度を示している. 本研究では, キャビティー領域の評価として，キャビティー開始角度 $\theta_{s}$ とキャビティー終端角度 $\theta_{e}$ を図に示すように定義した。開 始角度 $\theta_{s}$ は垂直位置からキャビティーの発生が始まる位置 までの角度であり, 終端角度 $\theta_{e}$ は垂直位置からキャビティ 一の後端部までの角度である。開始角度 $\theta_{s}$ は, 正面から観 察する画像を基に幾何学的関係から求め, 終端角度 $\theta_{e}$ は下 方から観察する画像を基に観察角度 $30^{\circ}$ を考慮し, 幾何学 的関係から求めた。

\section{3. 実験結果, および考察}

\section{1 キャビテーションの発生と成長}

Fig.3(a)には, $20 \mathrm{~N}$ 負荷時のキャビティーを下方から観察 した結果(白色光源下)である。黒線で囲んだ内部がキャビ ティー領域を示す。荷重を加えた直後, 軸受側方部から空

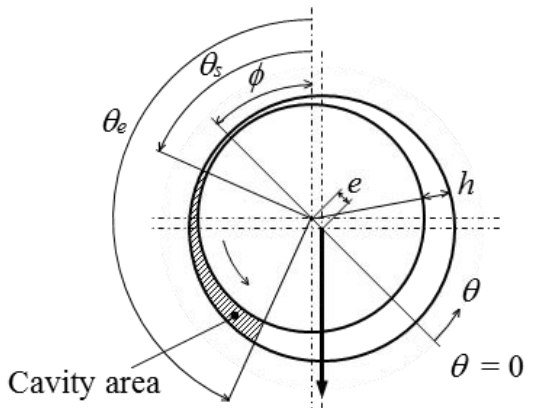

Fig.2 Definitions of cavity angle, $\theta_{\mathrm{s}}$ and $\theta_{\mathrm{e}}$ 


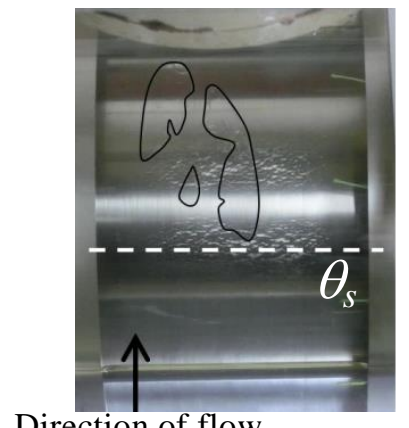

(a) At $20 \mathrm{~N}$

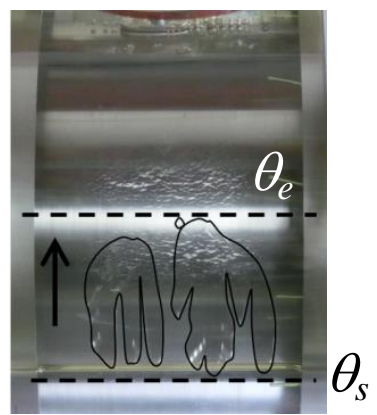

(b) At $30 \mathrm{~N}$
$10 \mathrm{~mm}$
Fig. 3 Photograph of cavity at 20 and $40 \mathrm{~N}$

\section{Direction of flow}

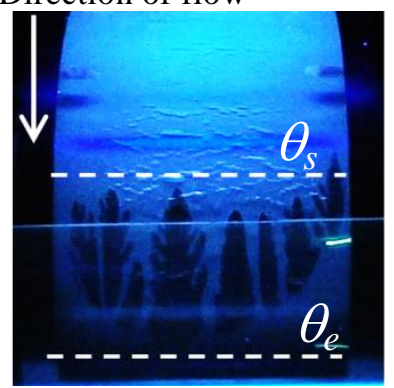

(a) At $0 \mathrm{~s}$

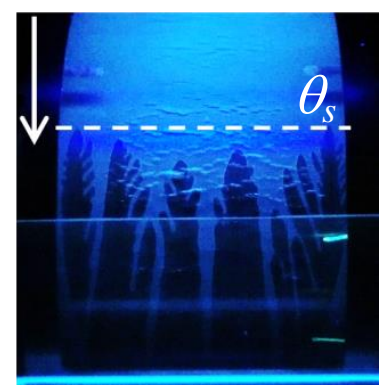

(b) At $120 \mathrm{~s} \quad 10 \mathrm{~mm}$
Fig.4 Cavity growth at $45 \mathrm{~N}$

気の吸込みが生じ，油膜内でキャビティーが発生した。キ ヤビティーは, 一定位置にとどまることはなく, $\theta_{s}=$ 約 $135^{\circ}$ から $\theta_{e}=225^{\circ}$ (給油口のある角度)の領域で前進, 後退を繰 り返した。また，その形状は円形に閉じた形や枝分かれし た形などに変化した ${ }^{2,3)}$. 軸受の各位置の測定結果より，垂 直，水平方向に振動していたことも分かった。

$30 \mathrm{~N}$ に荷重を増やすと, キャビティー領域が流れ方向と 逆方向に移動し, 開始角度 $\theta_{s}$ が約 $100^{\circ}$, 終端角度 $\theta_{e}$ が約 $152^{\circ}$ となった(Fig.3(b)). 形状は開始位置で枝分かれし, 後 端部は閉じた形 ${ }^{4)}$ となっている。 その後の時間において, キャビティーの大きさや各角度の変化はほぼ起こらなかっ た。 $40 \mathrm{~N}$ に荷重を増やすと， $30 \mathrm{~N}$ の時と同じく，キャビテ イー領域が移動し， $\theta_{s}$ が約 $77.5^{\circ} ， \theta_{e}$ が約 $130^{\circ}$ と小さく なった．なお，キャビティーの大きさは，20，30 N 時の側 方から発生する小さなキャビティーの数や大きさによって 変化するため, 実験によってその大きさは変化していた.

Fig.4には, 荷重を $45 \mathrm{~N}$ にした直後と $2 \mathrm{~min}$ 後のキャビ ティーの正面からの観察結果を示す。また，Fig.5 には， 2 $\min$ 間における $\theta_{s}$ と $\theta_{e}$ の時間変化を示す。測定は，軸受中 央部における位置で行った。 $45 \mathrm{~N}$ に荷重を増やすと, $\theta_{s}$ が 約 $70^{\circ}$ まで小さくなった. また, $\theta_{s}$ が小さくなると同時に, 側方から小さなキャビティーが発生し, これまでに存在し ていたキャビティーの後端位置で合体した。このキャビテ イーの発生と合体は連続的に起こり, キャビティー領域は 時間とともに拡大していく. Fig.5より，キャビティーの成 長とともに， $\theta_{s}$ は徐々に小さくなり， $\theta_{e}$ は徐々に大きくな ることが分かる. Fig.4からも分かるように，キャビティー は，成長とともに $\theta_{s}$ を小さく， $\theta_{e}$ を大きくするように拡が る.また，約 $20 \mathrm{~s}$ 以後には多くの小さなキャビティーが発 生し, キャビティーが急速に成長した。これにより，各角 度もそれぞれ $\theta_{s}=$ 約 $59^{\circ} ， \theta_{e}=$ 約 $173^{\circ}$ に大きく変化する. 約 $50 \mathrm{~s}$ 以後, キャビティーの成長は小さくなり, 各角度の 時間変化も小さくなる。 なお，この成長において，各角度 の変化する速度は側方からの小さなキャビティーの発生量 と関係しており，実験によって開始後早期にキャビティー

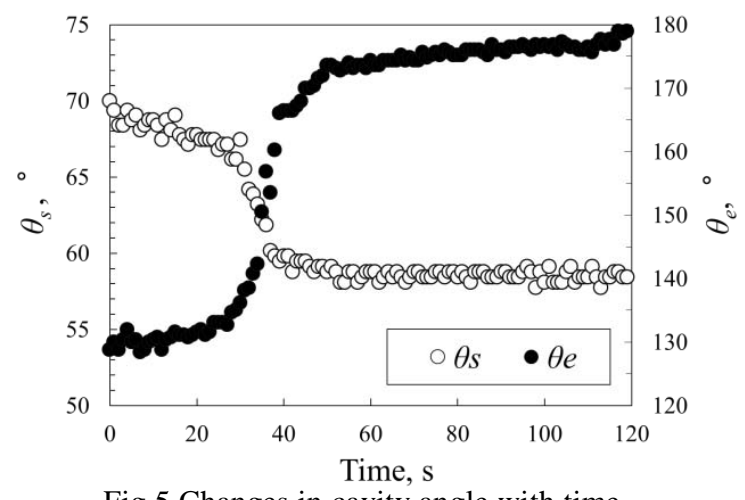

Fig.5 Changes in cavity angle with time

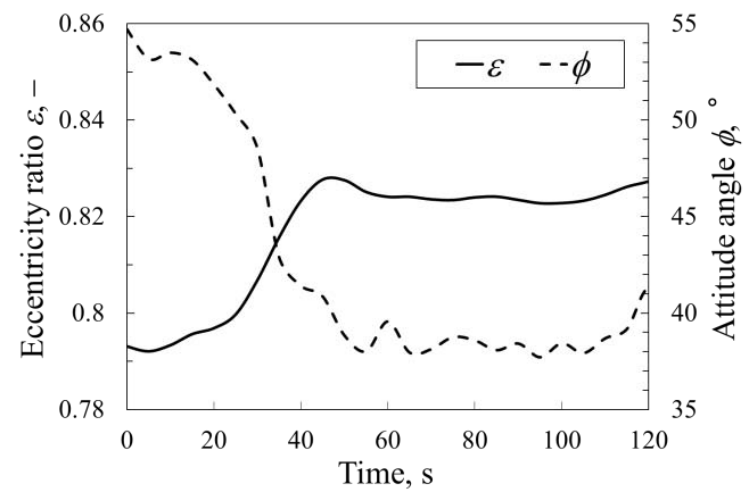

Fig.6 Changes in eccentricity ratio and attitude angle with time

が拡大し，各角度の変化が大きくなる場合もあった．

\section{2 キャビテーションの成長と偏心状態の関係}

Fig.6 は，荷重を $45 \mathrm{~N}$ にした直後から 2 min 間における 偏心率 $\varepsilon$ と偏心角 $\phi$ の変化を示したものである.この図より, $\varepsilon$ は時間とともに徐々に大きくなり， $\phi$ は徐々に小さくなる ことが分かる．また，約 $20 \mathrm{~s}$ 以後に大きく変化しており， $\varepsilon=$ 約 $0.83, \phi=$ 約 $39^{\circ}$ にそれぞれ変化する. その後， $\varepsilon, \phi$ に大きな変化は見られない. Fig.5 と比較すると, キャビテ イーの成長と偏心状態に関係性があることが分かる。キャ ビティーが成長すると, 最小油膜位置後方の拡がりすきま 部の完全油膜領域が小さくなるため, 圧力分布が変化する. その結果，例えばキャビティー圧を大気圧とした場合，負 荷容量の低下が起こる。しかし, 実験時の荷重は一定であ るので，必要な負荷容量を発生させるため，軸受は前方の 狭まりすきま部での圧力発生を高めるように，その位置を 変化させると考えられる。 そのため, キャビティーの発生 とともに $\mathcal{E}$ は大きく，仦さくなったと考えられる.

\section{4. 結言}

(1) $45 \mathrm{~N}$ での実験において，キャビティーは，時間ととも に軸受側方から発生する小さなキャビティーと合体す ることにより成長した。

(2) キャビティーの成長により，キャビティー開始角度は 小さく, 終端角度は大きくなった。

(3) キャビティーの成長は軸受の偏心状態を変化させ, 成 長とともに偏心率は大きく，偏心角は小さくなった．

\section{文 献}

1) T. Otsu et al., Trib. Int., 53(2012), pp.68-75.

2) 森ら, 日本機械学会論文集(第 3 部), 33, 248(1967), pp.658-666.

3) 和田ら, 潤滑, 16, 1(1971), pp.50-58.

4) D.Dowson, TRIBOLOGY, 1, 2(1968), pp.150-156.

\section{謝 辞}

本研究は, (財)JKA 平成 25 年度 機械工業振興補助事業 研究補 助(オートレース)により実施しました。ここに謝意を表します。 